УДК 81'276.3

DOI https://doi.org/10.26661/2414-1135-2021-82-28

\title{
КОМУНІКАТИВНО-СИТУАТИВНІ ПАРАМЕТРИ ВЖИВАННЯ АФЕКТОНІМІВ
}

\author{
Мокляк О. I. \\ кандидат філологічних наук, \\ викладач кафедри загального і слов'янського мовознавства та іноземних мов \\ Полтавський національний педагогічний університет імені В. Г. Короленка \\ вул. Остроградського, 2, Полтава, Україна \\ orcid.org/0000-0003-1883-1593 \\ oxana.mokliak@gmail.com
}

\author{
Ключові слова: \\ прагмалінгвістика, ласкаві \\ звертання, конситуація \\ спілкування, інтенціі, \\ перлокутивний ефект.
}

У статті здійснено аналіз особливостей уживання афектонімів звертань 3 іманентним позитивно-оцінним емоційним забарвленням на зразок квіточко, зіронько, коханий, такі номінації наділені певним магнетизмом, вони ніколи не залишаються поза увагою адресата. 3-поміж усіх можливих звертань досліджувані одиниці вирізняються чи не найбільшим регулятивним потенціалом, їм притаманна яскраво виражена спрямованість на співрозмовника. Афектоніми впливають насамперед на чуттєву сферу адресата, яку за допомогою таких номінацій схиляють зазвичай у бік позитиву та вдоволення.

У дослідженні представлено ядерні й периферійні ознаки функціювання ласкавих звертань у контексті аналізу основних компонентів комунікативного процесу, виокремлених свого часу Г. Лассвеллом та Р. Бреддоком. Афектоніми - це одиниці з виразним прагматичним зарядом, тож їх опис передбачає обов'язкове залучення таких комунікативно-ситуативних чинників уживання: хто говорить, кому, 3 якою метою, як саме, за яких умов і $з$ яким ефектом? У цьому плані релевантною постає характеристика соціальних рис комунікантів, котрі послуговуються зазначеними номінаціями, їхніх інтенцій, способу, сфери використання ласкавих звертань i перлокутивного ефекту, який стимулюють досліджувані апелятиви. Відповідно до вказаних параметрів, особливості функціювання таких одиниць репрезентовано у вигляді опозицій, перша 3 яких розкриває ядерні ознаки, друга - периферійні: а) за кількістю комунікантів: характерні для міжособистісного спілкування - для групової, масової комунікації; б) за інтерперсональними стосунками співрозмовників: уживаються між близькими людьми (закоханими, подружніми парами, батьками й дітьми, родичами, друзями) - використовуються між знайомими, незнайомими; в) за стратегіями: реалізують кооперативну стратегію - кооперативноконфронтативну, конфронтативну стратегії; г) за способом уживання: застосовуються безпосередньо - опосередковано; звертання до адресата постійно змінюються - за адресатом закріплюється певний афектонім 3 можливим варіюванням; д) за сферою спілкування: притаманні приватній комунікації - публічній; е) за ефектом: зумовлюють позитивний перлокутивний ефект - провокують негативний перлокутивний ефект. 


\title{
COMMUNICATIVE-SITUATIONAL PARAMETERS OF AFFECTONYMS USE
}

\author{
Mokliak O. I. \\ Candidate of Philological Sciences, \\ Lecturer at the Department of General and Slavic Linguistics and Foreign Languages \\ Poltava V. G. Korolenko National Pedagogical University \\ Ostrogradski str., 2, Poltava, Ukraine \\ orcid.org/0000-0003-1883-1593 \\ oxana.mokliak@gmail.com
}

Key words: pragmalinguistics, kind addresses, communication situation, intentions, perlocutionary effect.
The article analyzes the peculiarities of the use of affectonyms - appeals with immanent positive and evaluative emotional coloring such as a flower, a star, a lovely, such nominations are endowed with a certain magnetism, they never go unnoticed. Of all the possible appeals, the studied units have perhaps the greatest regulatory potential; they are characterized by a pronounced focus on the interlocutor. Affectonyms primarily affect the sensory sphere of the addressee, which with the help of such nominations is usually inclined towards positive and pleasure.

The study presents the nuclear and peripheral features of the functioning of kind addresses in the context of the analysis of the main components of the communicative process, identified at the time by G. Lasswell and R. Braddock. Affectonyms are units with a clear pragmatic charge, so their description implies the obligatory involvement of such communicative-situational factors of use: who speaks, to whom, for what purpose, how exactly, under what conditions and with what effect? In this regard, the description of the social features of communicators who use these nominations, their intentions, method, scope of kind appeals and perlocutionary effect, which is stimulated by the studied appeals, is relevant. According to the specified parameters, the peculiarities of the functioning of such units are represented in the form of oppositions. The first of them reveals nuclear features, the second one - peripheral: a) by the number of communicators: characteristic of interpersonal communication for group, mass communication; b) according to the interpersonal relations of the interlocutors: they get along between close people (lovers, married couples, parents and children, relatives, friends) - they are used between acquaintances, strangers; c) according to strategies: implement a cooperative strategy - cooperative-confrontational, confrontational strategy; d) by method of application: applied directly - indirectly; appeals to the addressee are constantly changing - a certain affecton with possible variation is assigned to the addressee; e) in the field of communication: inherent in private communication - public; f) by effect: cause a positive perlocutionary effect provoke a negative perlocutionary effect.
Постановка проблеми. Прагмалінгвістика, утвердивши антропоцентризм як засадничий принцип, передбачає аналіз мовних одиниць 3 погляду вживання їх людиною, яке відбувається за тих чи тих комунікативно-ситуативних умов. Формування нової функційно-комунікативної парадигми вивчення мови, спрямованої на пізнання природи й закономірностей людського спілкування, спонукало вчених звернути особливу увагу на елементи комунікативного процесу. У 1948 році американський політолог Г. Лассвелл запропонував лінійну модель комунікаціï, представлену формулою "Who says what to whom in which channel with what effect?" [1, c. 199].
Р. Бреддок удосконалив модель, додавши ще два важливі складники: умови, за яких відбувається комунікація, і мету спілкування адресанта [2].

Урахування зазначених аспектів дає змогу дослідникам (Г. Балакай, Р. Водак, В. Дєвкін, I. Корнійко, Н. Формановська та ін.) яскраво репрезентувати специфіку побутування тих чи тих мовних одиниць. Особливий науковий інтерес викликають звертання через ї здатність створювати прагматичний ефект, впливати на поведінку й емоційний стан адресата. 3-поміж апелятивів чи не найбільшим регулятивним потенціалом наділені афектоніми - звертання 3 іманентним позитивно-оцінним забарвленням 
на зразок зіронько, ясочко. Відсутність розвідок, які б комплексно висвітлювали проблему вживання афектонімів, а також посилення інтересу сучасної лінгвістики до таких комунікативно зорієнтованих одиниць, визначають актуальність дослідження.

У мовознавчій науці розглядувані нами апелятиви номінують по-різному: пестливі, ласкавi, ніжні, інтимні, компліментарні, кваліфікативні, емочійні, емочійно-оцінні звертання, звертання-характеризаиії, філоніми, афектоніми. У статті послуговуватимемося переважно терміном афектоніми, оскільки у вітчизняному й зарубіжному мовознавстві він набув статусу фахового позначення позитивно-оцінних звертань.

Метою дослідження $є$ з'ясування особливостей функціювання афектонімів у контексті аналізу основних складників комунікативного процесу.

Реалізувати зазначену мету дають змогу такі завдання: представити комунікативно-ситуативні параметри вживання афектонімів, визначити ядерні й периферійні ознаки використання вказаних апелятивів.

Об'єктом нашої уваги стали ласкаві звертання, ужиті в художніх творах українських письменників XIX-XXI століть, в інтимному епістолярію та живому розмовному мовленні.

Предметом дослідження $є$ застосування афектонімів в актомовленнєвій взаємодії.

Виклад основного матеріалу дослідження. Для розв'язання окресленої проблеми релевантною видається характеристика: 1) комунікантів (хто, кому?); 2) інтенцій (з якою метою?); 3) способу вживання (як саме?); 4) сфери (за яких умов?); 5) перлокутивного ефекту (з яким ефектом?).

\section{1. Опис комунікантів (Хто - кому?)}

Зважаючи на те що будь-яка комунікативна поведінка залежить від соціальних рис, статусних i рольових показників партнерів, уживання афектонімів також позначене впливом соціальних параметрів. Особливо важливим є ступінь знайомства співрозмовників, у контексті якого виявляються інші екстралінгвальні чинники - вік, стать, статус.

Як зазначає Н. Формановська, «у кожній групі комунікантів для «своїх» обираються одні вирази, а для «чужих»- інші» [3, с. 10]. За критерієм близькості співрозмовників виокремлено тричленну опозицію використання афектонімів: між близькими, знайомими, незнайомими. Зважаючи на той факт, що досліджувані номінації передовсім є одиницями мови для «своїх», логічним видається таке схематичне зображення співвідношення функціювання цих звертань у всіх трьох випадках:

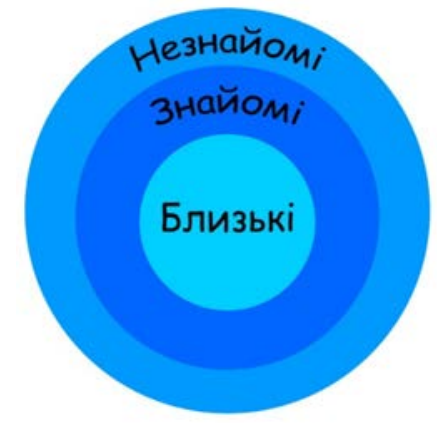

Ядро в схемі становлять ласкаві номінації у спілкуванні близьких комунікантів, навколоядерну частину - знайомих і периферійну - незнайомих.

Афектоніми - це одиниці, орієнтовані передовсім на близьких людей $(76 \%$ із зафіксованих уживань): закоханих (подружжя), батьків і дітей, родичів, друзів.

Ласкаві звертання вважають одним із основних складників романтичного спілкування, за допомогою них експлікують спектр емоцій і почуттів: від простої приязні й симпатії до любові й неймовірної ніжності (Кохана Галю, Скарбе Мій! (М. Левицький до дружини)). Функціювання афектонімів у любовній комунікації має двовекторний характер, «взаємне «перейменування» партнерів є характерним мовним засобом спілкування закоханих» [4, с. 95]. За спостереженнями дослідників, чим довірливішими є стосунки між людьми, тим різноманітніші апелятиви. «В інтимному любовному спілкуванні, - зазначає М. Кронгауз, - придумування нових імен-звертань стає особливим творчим актом, що виражає не менше емоцій, ніж інші діï» [5, с. 133].

В інтеракції ж батьків і дітей застосування афектонімів є однобічним: ними послуговуються здебільшого батьки. При цьому різноманітність досліджуваних номінацій, частотність використання залежать від віку адресата. Звертаючись до маленьких дітей, уживають низку креативних іменувань: гарбузик, кролик, горошок, комарик, карасик, динозаврик та ін. Такий розвій фантазії батьків зумовлений, вочевидь, їхнім наміром передати надмірну ніжність у ставленні до співрозмовника, а також відобразити грайливість, характерну для комунікації з малими дітьми. Справді, що менші діти, то більше ласкавих звертань уживають в адресованих їм висловленнях. Діти старшого віку, особливо підлітки, зазвичай негативно ставляться до подібних апелятивів, тому частотність і варіантність афектонімів у спілкуванні з ними різко знижується, ці номінації можуть узагалі зникнути 3 лексикону батьків, поступаючись іменуваннямідентифікаціям, тобто «парадигма форм звертання, релевантна для адресата-дитини, модифікується, коли ця дитина «перейде» в категорію дорослої людини» [6, с. 25]. 
Дитячий ідіолект позбавлений таких одиниць, як афектоніми, оскільки дитяче мислення спирається лише на конкретні образи. До їх апелятивного арсеналу належать звертання-ідентифікації, тому закономірно, що іноді діти прирівнюють й афектоніми до ідентифікацій: «Колись моя мала на запитання «Як звати твою маму?» відповіла: «Зая» (3 Інтернет-ресурсів). Указаний тип мислення зумовлює також прямолінійне трактування дітьми-адресатами звертань 3 переносним значенням, у них тільки починає формуватися самоусвідомлення, тому можна почути таку реактивну репліку на ласкаву номінацію: «Я не зайчик, $я$-Іванко». Дорослі діти лише під час надмірного емоційного піднесення вживають афектоніми у звертаннях до батьків.

У комунікації родичів домінантні позиції займають апелятиви-ідентифікації, афектоніми адресують зазвичай дітям, а дорослим співрозмовникам у хвилини найвищих душевних переживань.

У спілкуванні друзів також превалюють звертання-ідентифікації, афектоніми ж застосовують зрідка, щоб підкреслити особливість моменту, посилити вплив на адресата. Варто відзначити, що такими одиницями послуговуються здебільшого жінки, оскільки для них характерним є домінування емоційного начала. У фемінному мовленні концентрується велика кількість емоційно-оцінної лексики, тоді як у маскулінному - оцінна лексика тяжіє до стилістичної нейтральності й зниженості.

Основними екстралінгвальними чинниками, що впливають на функціювання афектонімів між знайомими, є вік і статус. Комуніканти, які перебувають у симетричних стосунках, вільно адресують афектоніми один одному за неформальних умов інтеракції. Асиметричні стосунки співрозмовників (викладач - студент, начальник - підлеглий) спричиняють невзаємне використання цих апелятивів, правом скорочення дистанції наділені лише особи зі статусом «вищий» або ж старші за віком: - Віталій, лапочка, вам не важко, -ловить мене в коридорі Маргарита Марківна. - Збігайте на третій поверх до Аполлінарія Калістратовича, занесіть nошту (П. Щегельський). Адресанти ж із «нижчим» статусом, молодші за віком, завжди дотримуються формально-ієрархічного характеру взаємин, порушують ці норми лише тоді, коли перебувають у стані надмірного емоційного напруження (наприклад, у ситуації благання). За таких умов «чинник соціальної належності поступається іншому, суттєвішому моменту - рівню емоційного напруження людини в процесі виголошення репліки, коли виявляється психологічна основа вживання тієї чи тієї форми звертання» [7, с. 28]. За даними нашого корпусу прикладів, така комбінаторика комунікантів становить $21 \%$. Для лексикону знайомих співрозмовників харак- терними $€$ стереотипні афектоніми, поширені в той чи той час (зайчику, золото, дорогий), які сприяють формуванню доброзичливих стосунків, але не виділяються надмірною емоційністю.

Пресупозицією побутування афектонімів $є$ неофіційність комунікації, ця особливість релевантна й для спілкування 3 незнайомцями. Такі одиниці $\epsilon$ нестереотипним явищем для вказаної інтеракції (3\%), однак саме «нестандартні звертання примушують адресата шукати причини такої мовленнєвої дії й формулювати їх у термінах прагматичної інтерпретації» [8, с. 220]. Використання афектонімів між незнайомими передбачає реалізацію двох тенденцій: вони можуть бути маркерами приязного або ж іронічного ставлення. Щоправда, здебільшого виконують роль регулятивів соціальної дистанції між співрозмовниками, уможливлюють iii скорочення, слугують установленню доброзичливого контакту.

Важливими соціальними чинниками, що позначаються на побутуванні афектонімів у спілкуванні незнайомих і сприймаються при безпосередньому контакті, $є$ вік і стать. Найпоширенішим $€$ застосування афектонімів комунікантами, старшими за віком, у такому разі гендер не відіграє вирішальної ролі. Типовими прикладами інтеракції за цієї комбінаторики співрозмовників $є$ довідкова бесіда, привертання уваги адресата, установлення доброзичливих взаємин: Богдана побачила розгубленість молодят, підійшла ближче... Як же тебе звати, зірко вечірня? (Л. Павленко). Менший за віком адресант може назвати незнайомого ніжно, перебуваючи в стані надмірного емоційного напруження, стать співрозмовника не має жодного впливу на функціювання афектонімів за цих умов:

\section{Бабусенько, голубонько,}

Серце моє, ненько!

Скажи мені щиру правду -

Де милий-серденько? (Т. Шевченко).

На вживання афектонімів однолітками впливає стать комунікантів, одностатеві співрозмовники зазвичай не використовують таких одиниць (особливо чоловіки, які, аби зменшити дистанцію 3 незнайомим, можуть послуговуватися номінаціями фамільярного характеру друже, земляче, але не ласкавими звертаннями). Афектоніми в комунікації різностатевих співрозмовників трапляються в ситуації залицяння. Оскільки залицяння - це прерогатива чоловіків, то саме чоловіки за таких умов інтеракції є адресантами: - Маю честь, красуне! Чим можу служити? - Ух, та й бравий! - обпекла жарким поглядом Дарка. - Ну чисто ж тобі генерал! - Для вас, красунечко, $i$ мариалом можу стати (Я. Баш). В українському континуумі ініціювання жінкою використання афектоніма на адресу незнайомого чоловіка 
вважається виявом непристойної поведінки. Лише іноді після встановлення контакту жінка може вжити афектонім із відтінком жарту, «підігруючи» чоловікові. Для порівняння зазначимо, що такими конвенціями не обмежене спілкування ромів. Узагалі афектоніми для цієї народності є чи не єдиним стереотипним звертанням до незнайомого співрозмовника: - Поворожу, соколику! - $i$ цчиганочка любо посміхнулась (О. Ільченко).

Зовнішність співрозмовника - найперше, що фіксує увага незнайомого адресанта, тому часто вживають звертання, пов'язані саме із цим аспектом: красуне, кралечко, чорнявий, чорноброва. Також послуговуються стереотипними одиницями на зразок голубко, сонце, зайчику, дорогий тощо. Публічного характеру набули афектоніми любий, люба, любі, на відміну від близьких їм за значенням коханий, кохана. Останні є маркерами інтимного спілкування двох близьких людей, хоча, як зазначає Н. Журавльова, «в епістолярію українських інтелігентів XIX - початку XX ст. субстантив коханий часто використовувався як етикетне поштиво-фамільярне звертання» [9, с. 192]: Так, коханий, - я маю право ие слово зажити, хоч і не знаю Вас особисто... (М. Старицький до П. Куліша).

Ласкаві звертання трапляються в різних видах комунікації - міжособистісній, груповій, масовій, але основою їх функціювання $\epsilon$, звісно, діадна взаємодія (89\%). Афектоніми, уживані у двоособових реляціях, сприяють саморозкриттю й проникненню у внутрішній світ партнера-комунікатора. Г. Почепцов справедливо називає їх одиницями «індивідуалізованої мови», призначеної лише для двох.

Для групової комунікації ласкаві звертання є менш характерними (8\%), адресатом у такому разі стають зазвичай діти (Учителька журно всміхнулась. - Ні, любі мої, до мене не прийдете, бо я їу далеко звідси. (М. Сиротюк)); зрідка - дорослі (Уже коли кузов наповнився, підійшли дівчата... Від ‘̈жджай, Гнате, черга за тобою. - До вечора, курчатка! - встиг крикнути Гнат (Л. Вернигора)).

Лише спорадично афектоніми виконують роль звертання до великої кількості людей (3\%), оскільки їх іманентною рисою $є$ приватність. Подеколи, щоб зреалізувати тактику солідаризації, такими одиницями в промовах послуговуються політики. Наприклад, Ю. Тимошенко, звертаючись до народу, використовує афектонім любі мої: Тримайтеся, любі мої (3 Інтернет-ресурсів); П. Порошенко - дорогі моӥ: Дорогі мої, ви тільки приступаєте сьогодні до служби, але вже кожен з вас став символом украӥнських реформ (3 Інтернет-ресурсів).

Афектоніми в незвичних для них груповій i масовій комунікаціях можна кваліфікувати як маркери додаткового соціального «поглажування», так мовець наближає до себе співрозмовника, зменшуючи ситуативно-статусний розрив.

2. Характеристика інтенцій (3 якою метою?)

Мовленнєвий намір здебільшого виникає й формується в адресанта ще до реалізації висловлення. Мовець планує й організовує хід мовленнєвої взаємодії з адресатом, обираючи такі вербальні засоби, які б з максимальною точністю виразили його інтенцію. Бажання адресанта досягти певних результатів своїми комунікативними діями зумовлює вибір ним стратегій і тактик, за допомогою яких він забезпечує ефективність впливу. Стратегію трактують як комплекс мовленнєвих дій, спрямованих на досягнення комунікативної мети, а комунікативні тактики - як «конкретні способи втілення стратегіi, спрямовані на певні зміни фрагментів свідомості адресата в потрібному для адресанта напрямі» [10, с. 240].

Поширеним є поділ стратегій на кооперативні й конфронтативні залежно від орієнтації на консенсус чи дисенсус. Таке виокремлення стратегій можна беззастережно екстраполювати також i на функційний простір розглядуваних у статті звертань. Основною, безперечно, є кооперативна стратегія вживання афектонімів, що зумовлено насамперед специфікою досліджуваних одиниць, які іманентно призначені для позитивного впливу на адресата, гармонізації стосунків комунікантів: - Годі ж, годі, моя перепілочко! Не плач, моя лебідочко! - каже їй Василь, пригортаючи до свого серденька (Г. Квітка-Основ'яненко). Протилежною кооперативній $є$ конфронтативна стратегія використання апелятивів, спрямована на відкриту дисгармонізацію: $A ч$, злодюга, куди поверта!. Не сховаєися, голубчику, від мене! (I. Карпенко-Карий). Але такий розподіл неповною мірою розкриває специфіку функціювання афектонімів, оскільки поза увагою залишається так зване нещире вживання розглядуваних одиниць. Уважаємо за потрібне доповнити класифікацію кооперативно-конфронтативною стратегією, що $є$ своєрідною проміжною ланкою між зазначеними вище, для якої характерна двоплановість: експліцитно мовець уявляє комунікацію як кооперативну, імпліцитно має на меті задоволення лише власних потреб за рахунок партнера шляхом завдавання йому моральної шкоди (конфронтативний аспект комунікаціi). Ця стратегія передбачає установку суб'єкта на спілкування, для якого характерна наявність відкритого й прихованого рівнів впливу з метою отримання односторонньої вигоди: В купе улешував: «Ластівко моя! Поїдемо співати, поїдемо медоносну південну природу сотати!» Ціле літечко співали, ціле літечко лагідненько південне повітря сотали. Коли ж досить наковталися і медоносне питво пішло через верх, 
Генріх показав оковпаченій жінці бубнового туза (О. Ковінька).

Реалізація трьох стратегій уживання афектонімів перебуває в такому співвідношенні:

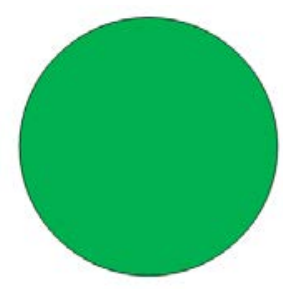

Кооператиєна стратегія

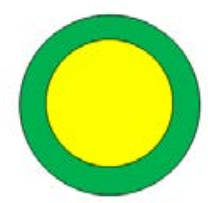

Кооператиеноконфронтатиена cmpamezія

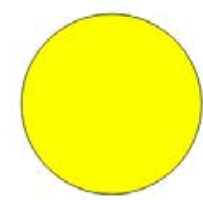

Конфронтативна стратегія
Отже, кооперативна стратегія $є$ домінантною, конфронтативна й кооперативно-конфронтативна - належать до периферійних. Зазначені стратегії можуть бути реалізовані низкою тактик.

3. Характеристика способу вживання (Як саме?)

Уживання афектонімів притаманне як контактному, так і дистантному (приватне листування, Інтернет-комунікація (форуми, чати, електронні листи), SMS, телефонні розмови) спілкуванню. Функційно активнішим є контактне використання афектонімів, оскільки безпосереднє мовлення природніше, крім того, адресант відразу може розпізнати, чи вдалося досягти бажаного перлокутивного ефекту. Застосовують афектоніми й у дистантній комунікації, зокрема в інтимному епістолярію. Щоправда, останнім часом традиція приватного листування, така поширена в XIX-XX століттях, дещо послабилася у зв'язку з домінуванням електронних технологій зв'язку. Але оскільки Інтернет-комунікація більше наближена до усного мовлення, то, звісно, утрачаються такі ознаки, як вишуканість форм, емфатичне нанизування тощо, типові для листових любовних звертань.

Вирізнено дві тенденції у використанні афектонімів: такі одиниці або мають змінюваний характер, постійно варіюються, або ж в інтимному, сімейному спілкуванні приживається якесь одне конкретне звертання, призначене для певного адресата. Цю специфіку апелятивів відзначають М. Епштейн, М. Мілевська, Я. Перлін, наголошуючи все-таки на домінуванні змінюваного вживання. Бажання внести щось нове в комунікацію з близькою людиною викликає в мовця потребу експериментувати, добирати нові, оригінальні звертання. Можливо, тут також спрацьовує закономірність адаптації сили прагмеми: чим частотніша прагмема, тим меншою прагматичною силою вона наділена. Трапляються ж ситуації, коли найбільш вдалі звертання, які позитивно сприймає адресат, стають постійними, традиційними. Цю особливість афектонімів як своєрідних парольних знаків зауважує Т. Ренц, їх «уживають партнери як маркери, що відрізняють одну романтичну діаду від іншої» [11, с. 10]. Аналізовані апелятиви, незважаючи на постійність застосування, не набувають характеру автоматизованих, зміна ритуалу звертання може спричинити зміну стосунків або сигналізувати про цю зміну: - Хто то? - запимую, намагаючись говорити спокійно. - Я щзе не женюсь, Славо (вже не «мишко») (Ірина Вільде).

Ніжні звертання в сімейному колі постають як засоби створення так званого «сімейного арго» (термін за В. Слістратовим), що виникає в діалозі двох закоханих чи всієї сім’ї. До апелятивів арготичного характеру належать як традиційні ласкаві словечка, так і новотвори самих членів сімейної спільноти, вдало підібране слово-звертання приживається і є знаком саме цієї соціальної групи. Такі одиниці, набуваючи характеру прізвиськ, можуть виконувати роль ідентифікаторів, тоді їх використовують і для ідентифікації носія іменування, i для вираження мовцем свого емоційно-оцінного ставлення до нього: Милая моя молоденька КнаКна! (Леся Українка до М. Косача) й Цілую тигрів i Кна-кну (Леся Українка до О. Косач (матері)).

У комунікації знайомих чи незнайомих співрозмовників уживання афектонімів має, зрозуміло, спорадичний характер. Однотипні одиниці за такої комбінаторики комунікантів свідчать не про кодовість звертання, а про особливість ідіолекту мовця, тобто «мова формує образ адресанта, визначає його «мовний паспорт» [12, с. 17]: ... у мене зайчик - слово-паразит. Зайчиком можу назвати $і$ хорошого продавия, $i$, зрештою, будь-кого, якщьо в мене хороший настрій (3 Інтернет-ресурсів).

\section{4. Характеристика сфери використання} (За яких умов?)

Вибір того чи того звертання залежить також i від умов спілкування, позаяк мовленнєвий акт - це не простий набір слів, що відтворюються в будь-якій ситуації, а унікальна подія, компонентами якої є певні особи, конкретний час і місце. Різна консталяція складників системи «я-ти-туттепер» регулює вибір форм апелятивів. Справді, на офіційному засіданні друзі не можуть уживати в ролі звертання афектоніми, які є релевантними для їхньої бесіди, наприклад, у кав’ярні. Так само чоловік i дружина на роботі звертаються одне до одного офіційно, що здавалося б дивним, але загальна мовленнєва поведінка вважає цей тип спілкування прийнятнішим.

Варто зупинитися детально ще на одній важливій умові функціювання афектонімів, представленій у вигляді кореляції приватність - публічність. Релевантною ознакою вживання цих апелятивів $є$ інтимність, для близьких співрозмовників такі найменування стають своєрідними табуйованимипозначеннями, які старанно 
приховують від інших і використовують лише наодинці. «Мова ласки» обслуговує двох конкретних людей, тому застосування афектонімів при сторонніх зазвичай спричинює висміювання, а миле адресатові звертання може перетворитися на неприємне прізвисько. Тож у присутності третьої особи закохані послуговуються звертаннями-ідентифікаціями, замість ласкавих номінацій, або вдаються до паралінгвальних захисних обмежень (говорять пошепки): Це у присутності дівиці Протасової, як $i$ завжди при сторонніх, князь звертався до імператриці на «ви», а віч-на-віч - «моя богине», «моє серце»... (П. Наніїв). Демонстративний характер уживання афектонімів засвідчено, коли: 1) комуніканти не приховують своїх стосунків і сподіваються на позитивну реакцію з боку третьої особи; 2) мовець намагається посилити приниження адресата за умов конфронтативної інтеракції; 3) стороння особа є непрямим адресатом.

До «привселюдних» афектонімів оточення ніколи не буває байдужим. У третьої особи вони викликають зацікавленість, здивування, захоплення тощо: Чоловік якось на весь магазин щчось мене питає $i$ каже «Пуся»... люди аж поолядалися (3 Інтернет-ресурсів). Це залежить від ситуації або міжособистісних стосунків комунікантів зі свідком їхньої інтеракції.

Нехарактерною є приватність для вживання афектонімів малознайомими чи незнайомими адресантами (особливо представниками сфери обслуговування), оскільки за таких умов за допомогою цих апелятивів експлікують не інтимні стосунки між комунікантами, а так звану «надввічливість».

5. Характеристика перлокутивного ефекту (3 яким ефектом?)

Використовуючи той або той афектонім, адресант укладає в нього певну ілокутивну силу, сподіваючись, що вона буде не тільки правильно розшифрована, а й викличе відповідну реакцію з боку співрозмовника. Отже, «опозиція «мовець - адресат» органічно пов'яжеться з опозицією «комунікативний стимул - реакція-відповідь» [13, с. 359]. У зв’язку 3 тим що чуттєва сфера підвладна впливові більше, ніж раціональна, афектоніми практично ніколи не залишаються поза увагою адресата. Справедливою є думка Н. Трофімової: «Якщо мовець особливо зацікавлений у тому, щоб вплинути на поведінку співрозмовника в бажаному для нього напрямі, він надає своєму мовленню афективного забарвлення, уживаючи особистісно-афективні форми звертань» [4, с. 94]. Позитивна чи негативна реакція на афектоніми детермінована їх адекватністю/неадекватністю для певної комунікативної ситуації. Звісно, афектоніми, зважаючи на їх емоційно-оцінне забарвлення зі знаком «плюс», здебільшого стимулюють виникнення бажаного позитивного ефекту, хоча трапляються випадки, коли такі звертання спричиняють комунікативні девіаціі, іноді взагалі призводять до припинення комунікації. Зазвичай негативна реакція $є$ виявом неінтендованого (непланованого) перлокутивного ефекту.

Висновки й перспективи подальших розробок. Отже, аналіз афектонімів через призму комунікативно-ситуативних параметрів дав змогу виокремити ядерні й периферійні особливості ï уживання, представлені нами, відповідно, у вигляді опозицій: 1) використовуються між близькими комунікантами - між знайомими, незнайомими; 2) призначені для двох комунікантів, міжособистісні - групові, масові; 3) реалізують кооперативну стратегію - реалізують конфронтативну, кооперативно-конфронтативну стратегіï; 4) характерні для контактного спілкування (безпосередньо) - характерні для дистантного спілкування (опосередковано); 5) звертання до адресата постійно змінюються - за адресатом закріплюється певний афектонім 3 можливим варіюванням; 6) уживаються приватно - уживаються публічно; 7) мають позитивний перлокутивний ефект - мають негативний перлокутивний ефект. Зважаючи на яскраво заманіфестовану спрямованість афектонімів на адресата, незаперечною є потреба їх подальшого вивчення в комунікативно-прагматичному аспекті, що передбачає розгляд інтенційного потенціалу ласкавих звертань, їх перлокутивної природи.

\section{ЛIТЕРАТУРА}

1. Широких О.В. Моделі комунікаційного процесу. Ученьле записки Таврического национального университета имени В.И. Вернадского. Серия «Филология. Социальные коммуникаųuи». 2012. Т. 25 (64). № 1. С. 199-203.

2. Тургаев А.С., Хренов А.Е. Политология в схемах и комментариях. URL: http://uchebnikonline.com/soderzhanie/textbook_267.html (дата обращения: 12.04.2015).

3. Формановская Н.И. Социально-культурная сущность речевого этикета. Московский лингвистический журнал. 2003. Т. 7. № 2. С. 9-20.

4. Трофимова Н.А. Обращение как оператор порождения реляционного смысла. Ното Loquеns: актуальные вопросы лингвистики и методики преподавания иностранных языков. Санкт-Петербург, 2010. Вып. 2. С. 92-100.

5. Кронгауз М.А. Обращение как способ моделирования коммуникативного пространства. Логический анализ языка. Образ человека в культуре и языке. Москва, 1999. С. 124-134.

6. Корнійко I.В. Звертання як динамічний засіб вираження зверненості мовлення (на матеріалі сучасної німецької мови) : дис. ... канд. філол. наук : 10.02.04. Київ, 2000. 186 с. 
7. Липатова М.К. Обращение как средство выражения эмоциональной оценки в современном французском языке : дисс. ... канд. филол. наук : 10.02.05. Ленинград, 1984. 180 с.

8. Карасик В.И. Язык социального статуса. Москва : Институт языкознания АН СССР, Волгоградский педагогический институт, 1991. 495 с.

9. Ж Журавльова Н.М. Поетика української епістолярної ввічливості XIX - початку XX століття : монографія. Запоріжжя, 2012. 548 с.

10. Селіванова О. Сучасна лінгвістика : термінологічна енциклопедія. Полтава : Довкілля-К, $2006.716 \mathrm{c}$.

11. Ренц Т.Г. Романтическое общение в коммуникативно-семиотическом аспекте : автореф. дисс. ... докт. филол. наук : 10.02.19. Волгоград, 2011. 42 с.

12. Стернин И.А. Системное значение как обобщение контекстуального употребления слова. Функиионирование языковых единии в контексте : сборник науч. трудов. Воронеж. гос. ун-та. Воронеж, 1978. С. 16-19.

13. Арутюнова Н. Д. Фактор адресата. Известия АН СССР. Серия «Литература и язык». 1981. T. 40. № 4. C. 356-367.

\section{REFERENCES}

1. Shyrokyh, O. V. (2012). Models of communication process [Modeli komunikatsiinoho protsesu]. Scientific notes of the V. I. Vernadsky Tavrichesky National University. Series: Philology. Social communications, vol. 25 (64), No. 1, pp. 199-203.

2. Turgaev, A. S., Khrenov, A. E. Political science in diagrams and comments. [Poliyologiya $\mathrm{v}$ shemah i kommentariyah]. URL: http://uchebnik-online. com/soderzhanie/textbook 267.html.

3. Formanovskaya, N. I. (2003). Socio-cultural essence of speech etiquette [Sotsialno-kulturnaya sushchnost rechevogo etiketa]. Moscow linguistic journal, vol. 7, 2, pp. 9-20.

4. Trofimova, N. A. (2010). Referencing as an operator of generating relational meaning [Obrashchenie kak operator porozhdeniya relyatsionnogo smysla]. Homo Loquens: topical issues of linguistics and methods of teaching foreign languages. SPb. Vol. 2, pp. 92-100.
5. Krongaus, M. A. (1999). Appeal as a way of modeling the communicative space [Obrashchenie kak sposob modelirovaniya kommunikativnogo prostranstva]. Logical analysis of language. The image of a person in culture and language. Moskow, pp. 124-134.

6. Korniiko, I. V. (2000). Addressing as a dynamic means of expressing the appeal of speech (on the material of modern German): dis. ... cand. philol. science [Zvertannia yak dynamichnyi zasib vyrazhennia zvernenosti movlennia (na materiali suchasnoi nimetskoi movy)]. Kyiv, $186 \mathrm{p}$.

7. Lipatova, M. K. (1984). Appeal as a means of expressing emotional appreciation in modern French: dis. ... cand. philol. science [Obrashchenie kak sredstvo vyrazheniya emotsyonalnoy otsenki v sovremennom frantsuzskom yazyke]. Leningrad, $180 \mathrm{p}$.

8. Karasik, V. I. (1991). Social status language [Yazyk sotsialnogo statusa]. Moskow: Institute of Linguistics of the USSR Academy of Sciences, Volgograd Pedagogical Institute, $495 \mathrm{p}$.

9. Zhuravliova, N. M. (2012). Poetics of Ukrainian epistolary politeness of the XIX - beginning of the XX century: monograph [Poetyka ukrainskoii eistoliarnoii vvichlyvosti XIX - pochatku XX stolittia]. Zaporizhzhia, 548 p.

10. Selivanova, O. (2006). Modern linguistics: terminological encyclopedia [Suchasna lingvistyka : terminolohochna entsyklopediia]. Poltava: Dovkillia-K, 2006, 716 p.

11. Rents, T. G. (2011). Romantic communication in the communicative-semiotic aspect: author. dis. ... dr. philol. sciences [Romanticheskoe ibshchenie v kommunikativno-semioticheskom aspekte]. Volgograd. $42 \mathrm{p}$.

12. Sternin, I. A. (1978) Systemic meaning as a generalization of the contextual use of the word [Sistemnoe znachenie kak obobshchenie kontekstualnogo upotrebleniya slova]. Functioning of linguistic units in context : collection of scientific papers of Voronezh State University. Voronezh, pp. 16-19.

13. Arutiunova, N. D. (1981) Addressee factor [Faktor adresata]. News of the Academy of Sciences of the USSR. Series: Literature and languages, vol. 40, No. 4, pp. 356-367. 